\title{
ENTREPRENEURSHIP AND INNOVATION IN EMERGING ECONOMIES / COMMUNITIES
}

\author{
Dav-Ernan Kowlessar \\ Business Development of MSME Sector \\ Halifax, Nova Scotia CANADA
}

Paradise is a small but proud community in the country of Heaven which boasts over seventeen thousand islands and has a population that ranks $4^{\text {th }}$ in the world. It is rich in its people and the variety of cultures and places to survive and live, but sadly, seeming not to thrive.

Like many other economies, they have lost productivity and income during the pandemic and lockdown measures which stymied international visitors, yet enhanced the Digital Economy in a way that they were not prepared for. In her future lies the fact that she will hold the post of President of the G20 in 2022 but its citizens are not necessarily motivated by this with the GDP per capita at USD 4,019 in 2019.

Many of the countries' demographics are changing as women in particular, have to pick up additional avenues of generating income as entrepreneurs and learning to trade outside of their traditional markets even whilst handling more domestic activity at home where they have a primary role of "child nurturing".

The participation of women in Micro, Small and Medium Enterprises (MSMEs) in Indonesia exceeds 60\% of a total estimated number of 57.83 million MSMEs; this was according to a July 2020 Report (Kemenko PMK). Women MSMEs are prevalent in three (3) main productive sectors: fashion, culinary and craft. The majority of these are operated on a small scale by women entrepreneurs. It should be noted that these women entrepreneurs account for a significant $21 \%$ of total entrepreneurs in Indonesia surpassing the global average by 13pp (Sasakawa Peace Foundation \& Dalberg, 2020).

Continuing along the trajectory of reality, there also exists a high level of awareness of the role of ICT in business, not only globally, but as Prakarsa (2020) conducted an online survey of women owned and operated MSMEs which produced several important findings. At least $50 \%$ or more of the Respondents stated that information technology was necessary to support to their business. They went further to identify the type of training they desired: $76 \%$ indicated that Marketing via the internet was important; $57 \%$ - Access to Online Capital; 48\% - Increased productivity; 44\%- for Financial accounting (The Prakarsa, 2020).

We must also consider the traditional path of individuals through Institutional learning based on old syllabuses, to new paths based on changing global trends and needs for new skills as the digital and creative worlds collide with the pandemic disruptions. As a Mc Kinsey report notes at the beginning of 2021; and a foundation for its current studies, "there will be a lasting impact on labour demand, mix of occupations and new workforce skills required". They go on to discuss further key ${ }^{1}$ Mc Kinsey; The Future of Work after Covid-19 February 182021 considerations, for example:

- The explosion in ecommerce resulted in an increase for warehouse workers who can interrelate with technology

- The investment swing into the green economy will require new skills in Agro-Technology

- Increase in trends for data visualisation may see the increase in use of photographers who were on the decline with desktop publishing and stock photos etc

Global reports suggest that a potential 1.5 billion youth may have been trained with the wrong job skills, and OECD projected the decline will be one of the worst, but a special edition of The Economist ${ }^{2}$ did note that there were some surprising changes where the surges declined by the end of 2020. They note that "Unemployment across the rich world rose from 5\% to 9\% in April 2020, in America, unemployment rose from $4 \%$ to $15 \%$ in one month. They further note that after 50 years of data from US, Canada, Australia and Japan, the analysis suggests that increases in unemployment happen fifty percent faster than declines (in GDP)"

In a most powerful editorial, which is a pivotal component of this paper, Singh and Gaur ${ }^{3}$ conclude that Entrepreneurship and innovation management have become imperative for the sustained growth and development of organizations across industries and political geographies. "The only global phenomenon and order of the day in the twenty-first century is entrepreneurship as it got power to propel economic growth of countries (Valliere and Peterson, 2009) and has truly become as much a social as an economic phenomenon (Thornton et al., 2011) across the globe.

To compete successfully, entrepreneurship and innovation management are the key competitive advantages in the globalized world and more so in the emerging economies which has in store the potential for tremendous growth opportunities. It has been found that the entrepreneurship and innovation are complementary as organizational success and sustainability in today's dynamic and changing environment depends upon the combination of these two - the entrepreneurship and the innovation (Zhao, 2005)."

We turn to some seminal work in 2006 by Coakes and Smith ${ }^{4}$ who speak to the concept of developing

\footnotetext{
${ }^{2}$ The Economist; Special Report "Labour Markets are working, but also changing", April 10, 2021

${ }^{3}$ Sanjay Kumar Singh, College of Business, Abu Dhabi University, Abu Dhabi, UAE, and

${ }^{4}$ Developing communities of innovation by identifying innovation champions.
} 
communities (of innovation) by identifying innovation champions, which then Sanjaya S. Gaur, Department of Marketing, Sunway University Business School, Subang Jaya, Malaysia Elayne Coakes and Peter A.C. Smith.

Continues producing more innovation as the cycle is repeated. They contend that "Innovation is essential to retain and improve organisations' market and competitive positions, and as such requires maximum internal support so that the current poor translation rate from idea to product is reduced. A community of innovation (CoInv) would greatly assist. In this paper we have argued that identifying champions of innovation will permit a CoInv network to be formed and that forming such a community will potentially trigger more innovations that are successfully supported."

They further define these (innovation) champions as special people with a particular personality type and psychological profile. As they continue in their conclusive statements, and we draw this reference that the community be considered the organisation in this case; " In order to succeed in championing innovations through the organisation, from idea and concept through to marketable product, they need not only procedural and resource support, but also social and cognitive support. We contend that this social support can be provided by a special type of CoP - a CoInv. We also contend that a CoInv provides important emotional support to champions and a fertile breeding ground for further innovations. It will also provide the shelter for knowledge entrepreneurs (Coulson Thomas 2003) to develop and thus provide greater stakeholder value for the organisation."

As this story unfolds, we know that people have the instinct within their DNA for survival- just as their bodies produce anti-bodies for viruses that may enter their system. Life is however not made up of the multitude of stories that are viewed almost every minute on a digital medium and it is to an old adage that we turn for our survival where it is said that "it takes a village to raise a child".

\section{INDONESIA ECONOMY}

The COVID-19 crisis triggered a decline in household consumption (that typically accounts for between 55-60 percent of Indonesia's total economic growth) of 4.04 percent (y/y). Gross fixed capital formation (contributing over 30 percent to economic growth) contracted 6.48 percent $(y / y)$ in Q3-2020, while exports of goods and services contracted 10.82 percent (y/y).

The only optimistic news is that the economic contraction in Q3-2020 was not as wide as in the preceding quarter (when the economy contracted by 5.32 percent $\mathrm{y} / \mathrm{y}$ ). This was also in line with expectations since most of the restrictions were eased in the third quarter, and thus now allow more room for economic activity.

Most likely there will be another small improvement in Q4-2020. However, we do still expect to see negative growth in the last quarter of 2020 (as well as in the first quarter of 2021 considering it is unlikely that a safe
COVID-19 vaccine will become available in the next couple of months).

Indonesia's Gross Domestic Product Growth per Quarter (annual \% change);

\begin{tabular}{|c|c|c|c|c|c|c|}
\hline Quarter & $\mathbf{2 0 1 5}$ & $\mathbf{2 0 1 6}$ & $\mathbf{2 0 1 7}$ & $\mathbf{2 0 1 8}$ & $\mathbf{2 0 1 9}$ & $\mathbf{2 0 2 0}$ \\
\hline Q1 & 4.71 & 4.94 & 5.01 & 5.06 & 5.07 & 2.97 \\
\hline Q2 & 4.66 & 5.21 & 5.01 & 5.27 & 5.05 & -5.32 \\
\hline Q3 & 4.74 & 5.03 & 5.06 & 5.17 & 5.02 & -3.49 \\
\hline Q4 & 5.04 & 4.94 & 5.19 & 5.18 & 4.97 & \\
\hline Full-Year & $\mathbf{4 . 8 8}$ & $\mathbf{5 . 0 3}$ & $\mathbf{5 . 0 7}$ & $\mathbf{5 . 1 7}$ & $\mathbf{5 . 0 2}$ & \\
\hline
\end{tabular}

Source: Statistics Indonesia (BPS)

Indonesia's national debt in 2019 was $\$ 341,498$ million dollars (30.49\% debt-to-GDP ratio), and its public debt per capita is $\$ 1,279$ per citizen. In terms of its human development index (HDI), which is the index used by the United Nations to measure the progress of a country, this was 0.718 points in 2019 , leaving it in $108^{\text {th }}$ place in the table of 189 countries published.

\section{SOCIO-POLITICAL}

Indonesia is a democratic state. All the considerations and decisions of the country belong to the citizens of Indonesia. There are some values that are generated from the fourth principle of Pancasila.

\section{Values of Democracy}

Democracy is made to create the equal right of taking a decision in a country. All of Indonesians people without any exception could be involved in making any decisions in the country. They could also give some opinions toward some policy. Their opinion would be distributed by the Indonesian house of representative called DPR. This value of democracy could create the critical citizens in Indonesia.

\section{The value of 'gotong royong' (mutual cooperation)} Gotong royong in Indonesia means helping each other. Indonesians are typically like to live in a group or collective. They would kindly help somebody else. Making decisions together is a habit in Indonesians. That is why when they have a trouble with others, they would like to discuss it first without using any violence. The diplomatic way is the best consideration to get a solution of the problem.

\section{THE CREATIVE ECONOMY}

The creative economy has no single definition. It is an evolving concept which builds on the interplay between human creativity and ideas and intellectual property, knowledge and technology. Essentially it is the knowledge-based economic activities upon which the 'creative industries' are based.

\section{Canada's Creative Industries ${ }^{55}$}

Creative entrepreneurs and creative workers are a vital and vibrant component of Canada's economy, ${ }^{5}$ Brookefield Institute for Innovation + Entrepreneurship 
from solo-production crafters, muralists, tattoo artists, and illustrators to internationally competitive companies in video games, animation, VR, software, film, and the world of dance, theatre, and galleries. Creative work spurs innovation and knowledge transfer across all sectors of the economy, creating commercial and cultural value, and income and employment opportunities. It is a critical input into non-creative sectors and businesses. Statistics Canada estimated that the direct economic impact of culture industries, including visual art, performing art, literature and publishing, music, media arts and screen-based industries, was $\$ 53.1$ billion in 2017 . The Conference Board of Canada forecast that it would contribute 15 percent in GDP growth and 8 percent in employment growth between 2017 and 2026. However, creative businesses and organizations have taken a hard, direct hit from the 2020 pandemic and public health rules forbidding public gatherings, events, and non-essential inperson work.

Within these cultural industries, women and non-binary artists, creative business owners, and artsorganization leaders are represented across artistic professions and sectors, leading some of the most innovative and successful businesses and artistic practices. According to the OECD, the proportion of selfemployed creatives is increasing globally, largely due to the precarious nature of creative jobs, including a rise in contractual forms of work, multiple job holding, and noninstitutional support. For 69 percent of countries surveyed by UNESCO in 2017, there were more women who were self-employed in creative sectors than in non-creative sectors. 35-40 percent of Canadian women with creative occupations are self-employed, compared to 10-15 percent of self-employed women outside of the creative industries. It is a group that generally experiences lower earnings, income fluctuations, and limited access to benefits, paid sick leave, etc.

Although virtual arts and culture consumption is increasing, and new programming, mediums, and dissemination channels are making content more accessible to those with a fast internet connection and home devices, it has not compensated for the full loss of income and business to individual artists, arts organizations, and creative businesses during the pandemic, and the future is uncertain for this vital sector. In order to build a resilient economic recovery, we will need to find ways to support this sector and this workforce, and to create safer futures for performance, collaboration, and convenings.

\section{Digital Commerce and the Digital Economy}

The World Economic Forum's O'Halloran and Barker (2019) have noted that the Fourth Industrial Revolution - which is driving the rapid growth of the global digital economy is enabled by new digital and physical technologies with almost limitless applicability and huge implications for the economy and society.
New business models are being leveraged not only by emerging organizations, but also by traditional entities, which view them as either complementary to wellestablished models, or as potential replacements of their core businesses. The subsequent economic disruption has indeed been revolutionary. In a few short years, the ranking of most valuable companies by market capitalization has totally shifted to being dominated by one business model - digital platforms and ecosystems.

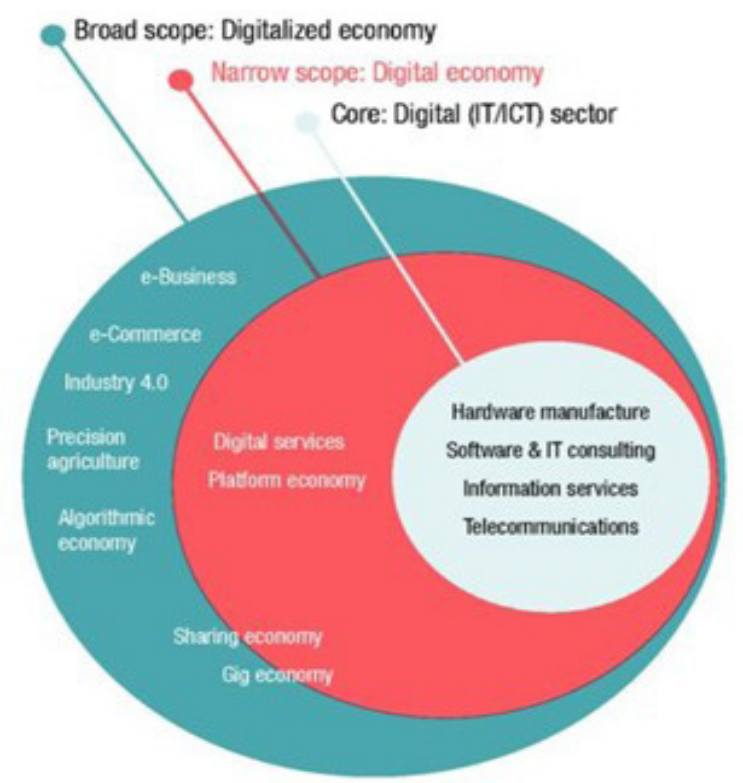

Figure 1. A simplified representation of the global digital economy in reference to the broader digitalized economy and the core digital (IT/ICT) sector

Source: Digital economy report 2019 p. 26

The World Economic Forum (WEF) has further estimated that by $2022,60 \%$ of the global GDP will be digitized. To this end, within the Americas, it is critical that countries be fully aware of the extent to which digitalization and internationalization have transformed and disrupted economic variables such as:

- value chain efficiencies

- value creation and delivery infrastructure

- access to resources

- workforce availability

- internal capabilities

While larger, more developed countries may be able to take full advantage of this disruption, smaller, less developed economies, including large emerging economies like Indonesia are at risk of being fully disrupted and marginalized.

Replacement online solutions and activities for physical shopping were forced on the population due to the various "lockdown"/"stay at home" measures introduced by Governments, with Google's community mobility data recording large falls in visits to retail and entertainment venues and to grocery and pharmacy establishments.

These adjustments appeared to have been sustained throughout the ongoing pandemic with the 
available evidence showing strong growth in the number of businesses selling online, with many businesses establishing new digital sales platforms, and growth in the share of online sales compared with physical stores

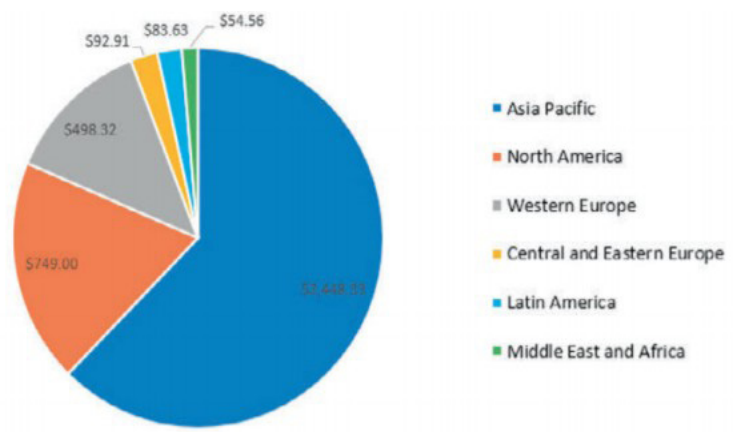

Figure 2. Global Share of retail e-Commerce Sales by region (2020)

Source: COVID-19 and e-Commerce: a Global Review p. 45

\section{CONCLUSION}

The old battle between private sector and civil society need not continue- the disruption of our current time calls for new building; new hope and managing through the new trajectory. The collision and emerging creative and digital economies can be combined with the UVP of Indonesia with its strong Paradise communities.

The models already exist for Paradise communities to develop and incorporate new syllabuses at the primary and secondary level, both in Indonesia and the rest of world. As an example, there is an introductory course for cooperatives who want to apply the "Tanggung Renteng" system. Tanggung Renteng or Joint Responsibility is a classic system and local wisdom in Indonesia (especially Javanese) to solve the problem together. In term of cooperatives, it is "Joint responsibility among members in one group for all obligations towards the cooperative based on openness and mutual trust." And there are 3 elements to be implemented such as groups, obligations, and regulations

The pandemic has resulted in less visitors to Indonesia, thus creating ripple effects on the craft trades, tours and tourism sectors whilst placing a strain on learning potentially new technologies which are made easier access by the International community who were quicker to market. The capability to harness this power within Indonesia should be managed towards optimisation through strong leadership.

Indonesia can still capitalise on these opportunities by taking Indonesia to the world. Sectors are reopening in different versions; innovation abounds when uncertainty is rampant. People are online a lot more; gaming communities means that entire new worlds such as that which exist in Indonesia, can be visited by the world.

Our Paradise community already has the ability to work as a community and thus are quite capable of mothering champions of innovation. These champions of innovation and entrepreneurship should be supported, just like we would in sport or other platforms.

\section{Bibliography}

Management Decision; Vol. 56 No. 1, 2018 pp. 2-5 (C) Emerald Publishing Limited 0025-1747 DOI 10.1108/MD-11-2017-1131

The future of Work after Covid-19, Mc Kinsey February 18, 2021 https://www.mckinsey.com/featuredinsights/future-of-work/the-future-of-work-aftercovid- 19

The Economist; Special Report "Labour Markets are working, but also changing”, April 10, 2021 https:// www.economist.com/special-report/2021/04/08/ labour-markets-are-working-but-also- changing

A portrait of Creative Entrepreneurship and the Creative Economy in Canada; November 2020,

Brookfield Institute for Innovation + Entrepreneurship

https://brookfieldinstitute.ca/a-portrait-of-creativeentrepreneurship-and-the-creative- economy-incanada/

Developing communities of innovation by identifying innovation champions.

Elayne Coakes1 and Peter A.C. Smith2

1 Westminster Business School, University of Westminster

2 The Leadership Alliance Inc., Holland Landing, Canada

An electronic, author-formatted version of an article published in The Learning Organization, 14 (1). pp. 74-85, 2007. The definitive version in The Learning Organization is available online at: http://dx.doi. org/10.1108/09696470710718366 